\title{
e norden
}

\section{Contingency Planning for Animal Diseases}

The Proceedings of a Nordic-Baltic Seminar on "Contingency Planning for the next Decade" held 19-20 September 2012 Helsinki, Finland
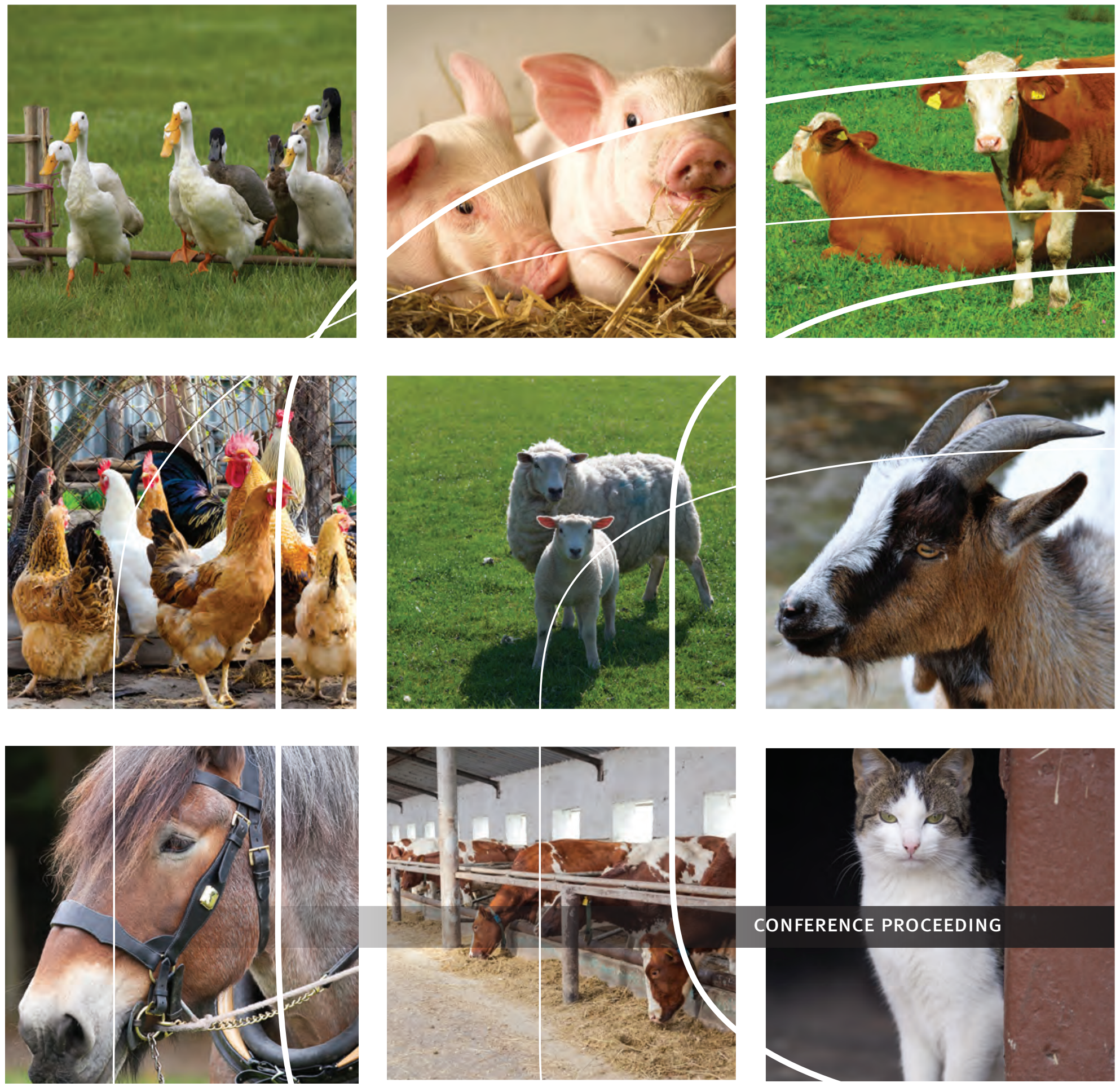

4 norden 



\section{Contingency Planning for Animal Diseases}

The Proceedings of a Nordic-Baltic Seminar on "Contingency Planning for the next Decade" held 19-20 September 2012 Helsinki, Finland 
Contingency Planning for Animal Diseases

The Proceedings of a Nordic-Baltic Seminar on "Contingency Planning for the next Decade" held 19-20 September 2012 Helsinki, Finland

ISBN 978-92-893-2711-4

http://dx.doi.org/10.6027/TN2014-509

TemaNord 2014:509

ISSN 0908-6692

(C) Nordic Council of Ministers 2014

Layout: Hanne Lebech

Cover photo: ImageSelect; Jørgen M. Westergaard

This publication has been published with financial support by the Nordic Council of Ministers. However, the contents of this publication do not necessarily reflect the views, policies or recommendations of the Nordic Council of Ministers.

www.norden.org/en/publications

Nordic co-operation

Nordic co-operation is one of the world's most extensive forms of regional collaboration, involving Denmark, Finland, Iceland, Norway, Sweden, and the Faroe Islands, Greenland, and Åland.

Nordic co-operation has firm traditions in politics, the economy, and culture. It plays an important role in European and international collaboration, and aims at creating a strong Nordic community in a strong Europe.

Nordic co-operation seeks to safeguard Nordic and regional interests and principles in the global community. Common Nordic values help the region solidify its position as one of the world's most innovative and competitive.

\section{Nordic Council of Ministers}

Ved Stranden 18

DK-1061 Copenhagen $\mathrm{K}$

Phone (+45) 33960200

www.norden.org 


\section{Content}

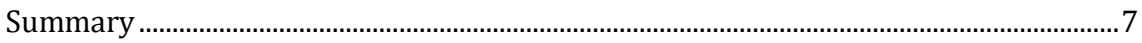

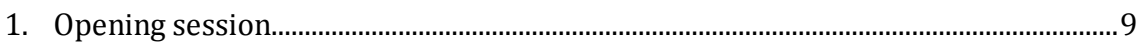

2. Abstracts .......................................................................................................................... 11

2.1 Session I. Contingency planning at international and national level........... 11

2.1.1 The future livestock production - trends, challenge, threats and opportunities................................................................................. 11

2.1.2 What is contingency planning in the area of animal health? .............12

2.1.3 The OIE and Global Contingency Planning.......................................... 13

2.1.4 The legislative framework for contingency planning in the EU .......... 14

2.2 Session II. Contingency planning - Data collection, storage and handling of disease data............................................................................. 15

2.2.1 The IT-sector's views on transmission, collection, storage and distribution of data is disaster situations ....................................... 15

2.2.2 Handling of data related to disease outbreaks .................................... 16

2.2.3 The development and use of LEIF for animal health emergencies ........................................................................................... 17

2.3 Session III. Contingency planning for the next decade - the veterinarian in the private sector, equipment and financing ....................... 19

2.3.1 Contingency planning and veterinarians in private practices providing services to the livestock industry ........................................ 19

2.3.2 Review of equipment available for use in the field during major disease outbreaks.

2.3.3 The interaction between the farmer, the livestock industry and official authorities during disease emergencies - How to succeed?

2.3.4 Financing of measures related to preventing, controlling and eradicating infectious diseases in livestock, poultry and live fish. Who shall pay?

2.4 Session IV: Bio-terrorism and contingency planning .................................... 23

2.4.1 Bio-terrorism and biological contingency planning............................ 23

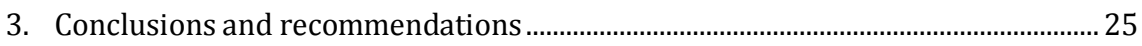

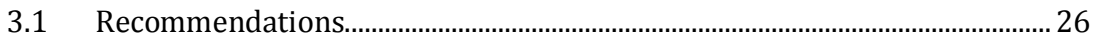

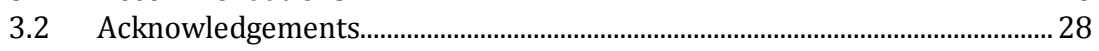

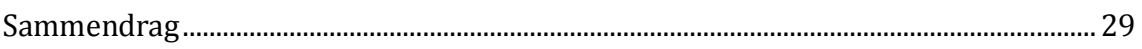

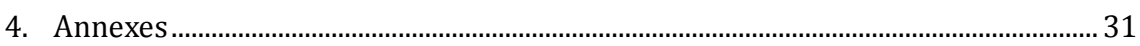

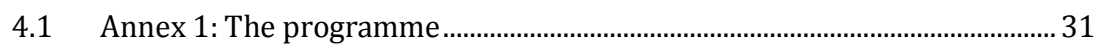

4.2 Annex 2. The Organizing Committee ................................................................ 33

4.3 Annex 3. List of participants................................................................................ 34

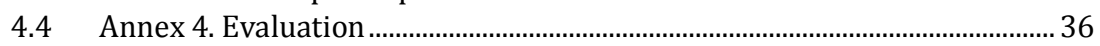

4.4.1 Complementary comments to evaluation form................................... 39

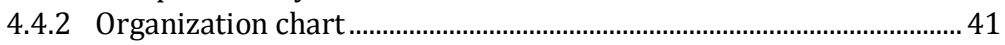





\section{Summary}

The Nordic -Baltic seminar on Contingency planning for the next Decade was held in Helsinki, Finland from 19-20 September 2012.

The objectives of the seminar were to elucidate the following issues:

- Contingency planning at international and at national level.

- Challenges facing veterinary administrations at central, regional and local level and livestock industries in contingency planning.

- Legislation and contingency planning.

- Desirable Databases - software and hardware - for contingency planning and implementation of disease control measures.

- Globalization and animal health threats.

Furthermore, the seminar had focus on needs and methods for preparation, up-dating and testing contingency plans in the area of Animal Health.

The first day of the seminar highlighted the potential future livestock production systems, the main elements and challenges within the area of contingency planning at National and Global level and the legislative framework for contingency planning at the EU level. The second day had focus on collection, storage and distribution of data during disease emergency situation, the importance of services provided by private practitioners to the livestock sector, equipment for use during major disease outbreaks, the interaction between the farmer, the livestock industry and official authorities during disease emergencies, financial matters and certain aspects of bio-terrorism.

The seminar showed the importance of having constructive dialogues and close cooperation between scientists, legislators, private and official veterinarians, administrators, the livestock industry and managers involved in contingency planning. The participation of representatives from World Organisation for Animal Health (OIE), the European Commission (EC), the Federation of Veterinarians of Europe (FVE) and the UK Veterinary Services provided valuable information on disease control measures applied outside the Nordic-Baltic countries. The participants of the seminar accepted the views that contingency planning in the area of animal health should cover: 
- The pre-epidemic period ("Peace time").

- The epidemic period, ("War time").

- The post-epidemic period (Time of rehabilitation).

The activities to be carried out during the three different periods are closely related but nevertheless require different training programmes to ensure the presence of adequate skills.

The presentations made during the seminar and a panel discussion on biosecurity provided an excellent basis for a valuable exchange of views between the experts from the participating countries. Based on the exchange of views during the seminar 5 recommendations were adopted; the recommendations were covering aspects of:

- Biosecurity.

- Simulation exercises.

- Partnerships in contingency planning.

- It-programmes and software.

- Bioterrorism.

The full text of the recommendations is given in the section: Conclusion and recommendations. 


\section{Opening session}

The participants of the seminar were at the opening session welcomed by Dr. Matti Aho, Chief Veterinary Officer of Finland and by Audur Lilja Arnthorsdottir, chairman of the Nordic-Baltic Veterinary Contingency Group.

In the opening speech Dr. Matti Aho expressed a warm welcome to all the participants and the pleasure of seeing so many experts coming to Helsinki for exchanging views and discussing the important issues of contingency planning in the area of animal health. Thanks were expressed to the organizing Committee for choosing Finland as host country for the seminar and the best wishes were given for a success of the seminar.

The speech given by Dr. Audur Arnthorsdottir is presented belov.

\section{Ladies and gentlemen}

As chairman of the Nordic-Baltic Veterinary Contingency Group, I wish to welcome you to the seminar "Contingency Planning for the Next Decade." - I will start by saying a few words about the background and the purpose of the group behind this arrangement.

In 2006, the Nordic Council of Ministers adopted a strategy which included plans for a closer cooperation between the Nordic and Baltic countries in the field of veterinary contingency planning. The plan emphasized that exotic animal infectious disease, with zoonotic potential as well as emerging diseases, should be prioritized. Subsequently the Nordic-Baltic Veterinary Contingency Group was established. The group consists of members from the veterinary authorities of the Nordic and the Baltic countries. The main purpose of the group is to achieve a common understanding of the risks related to introduction of exotic infectious animal diseases between key personnel in the veterinary administrations and scientific institutions. In addition the aim is to enhance awareness of epizootic diseases, to identify areas of improvement in veterinary contingency planning and build bridges between veterinary administrations of the Nordic and the Baltic countries. In order to reach its goal, the group has arranged a number of activities during the years. Those include international simulation 
exercises on epizootic diseases, seminars with invited speakers, expert meetings, training activities and observer activities on international exercises. The group members keep a close contact through e-mails and at least three meetings every year. Fortunately, the membership of the group has been quite stable, which contributes to a productive and efficient performance.

Now I will present the current members of the group. From the host country for this seminar, Finland, comes Sirpa Kiviruusu, from Estonia Maarja Kristian, from Latvia Edvins Olsevskis, from Lithuania Egidijus Pumputis, from Denmark Camilla B. Andersen and Hanne M. Hansen, from Sweden Elisabet Lindal, from Norway Siri Løtvedt and finally I from Iceland. Last but not least I will present the group's consultant Dr. Jørgen Westergaard who has been an invaluable support for the group from the very beginning. I took over as chairman in the beginning of this year from Joakim Holmdahl from Sweden. Before him was Eivind Liven from Norway. Prior to this Nordic-Baltic group, a Nordic group on veterinary contingency planning had existed for two years and the chairman of that group was Sten Mortensen from Denmark.

And now a few words about the objectives of the seminar. As the title indicates we will try to look into the near future and consider how the veterinary administrations should prepare for potential crises in the field of animal health; which knowledge and tools are available and which need to be developed. Hopefully, after these two days, we will know more and be better prepared to deal with future crises in this area. We should not forget that one purpose of participating in a seminar is to get to know other people in the same profession - and this is even more important at a seminar regarding contingency planning than any other topic, as it's invaluable to know people who you can get in touch with in the event of crisis.

In a few minutes Sirpa Kiviruusu, who is the head of the organizing committee for the seminar will give you some practical information about the arrangement. I wish you a pleasant stay and I sincerely hope you will benefit from attending the seminar.

Thank you. 


\section{Abstracts}

\subsection{Session I. Contingency planning at international and national level}

\subsubsection{The future livestock production - trends, challenge, threats and opportunities}

Jan Dahl, DVM, Chief Advisor, Danish Agriculture and Food Council

There are two trends going in opposite directions and posing different challenges to contingency planning. At the global level demand for meat is rising due to substantial increases in income for countries like China, India, and Brazil. Pork consumption increases by app. 2\% per year in China. In many countries all over the world industrial animal production is consolidating. Herds are getting bigger, production is professionalized, and herd level biosecurity is improving.

The other trend is less intensive production systems, claiming better animal welfare, better food safety, more environmentally friendly. Although some of the claims are questionable, this segment is also going to grow, but not in a very consistent way. Some areas like mountain farming the way it is seen in the alpine regions and in Scandinavia is reducing, but larger, professional organic farms are taking over.

The structure of farming in developing countries is probably going to be very diverse. Countries like Brazil will have an increase in professional pork and broiler production. Other developing countries will probably reduce the production.

Trade of meat and livestock products will increase for several reasons. Some countries do not have sufficient arable land to sustain a large animal production. Others can produce very effectively.

From a contingency planning perspective the mixture of professional production and alternative production forms can pose a challenge, since part of the alternative production forms are operated by less professional producers.

Global warming and the migration of new species into new areas (wild boar moving North in Europe as an example, new vectors for viral 
and bacterial infections) will challenge the production. This can especially be a challenge in the alternative production systems.

At the EU-level one of the challenges can be the balance between free trade and biosecurity. Free trade can encourage people to optimize the short term benefit by taking large risks that can impose large costs to the entire production. Finding the balance between profit, risk and regulation can be difficult.

\subsubsection{What is contingency planning in the area of animal health?}

Jørgen M. Westergaard, DVM, ADC-Consult, Denmark

Contingencies are relevant events that may or may not happen, including low-probability events that would have major impact. In the area of animal health the events could be a highly infectious disease (an exotic disease) such as African swine fever (ASF), avian influenza (AI), Classical swine fever (CSF) and foot and mouth disease (FMD) or spread of a toxic agent. The objectives of contingency planning are to protect animal and human health, to minimize economic loss for the livestock sector and the society as a whole and to minimize damage to the environment.

The importance of contingency planning in the area of animal health has been recognized by international organizations such as FAO, OIE, WHO by issuing guidelines and standards, by the Nordic Council of Ministers through a resolution in 2005 and by the EU through veterinary legislation.

Outbreaks of livestock diseases within the last 10-15 years in some highly industrialized countries have shown how vulnerable agricultural systems can be when confronted with an outbreak of a highly infectious disease.

All Member States of the EU and EFTA Members have within the framework of contingency planning prepared contingency plans. The criteria for such plans were primarily prepared in the early 1990s when large parts of Europe ceased the use of routine vaccination against FMD. The criteria drawn up at that time had focus on FMD outbreak management. Since then plans have been prepared for a number of infectious diseases; it is evident that contingency planning now and in the next decade must cover measures in: 
- the pre-epidemic period; disease prevention and preparedness

- the epidemic period; control and disease eradication

- the Post-epidemic period; repopulation of holdings and regaining of animal health status at international level.

In contingency planning it should be kept in mind that control and eradication of disease is often not a technical challenge. The challenge during outbreaks relates frequently to resource management, public relations, information management and endurance. During the pre-epidemic period the challenge is decision making.

\subsubsection{The OIE and Global Contingency Planning}

Alain Dehove, DVM, Co-coordinator of the World Animal Health and Welfare Fond, OIE

Owing to the increase of animal, people, products and pathogens circulation worldwide and the growing demand for animal proteins and the number of persons economically dependent on livestock, animal diseases and zoonosis have become a major global issue, and their control has been defined as a global public good.

The OIE is the intergovernmental organisation (178 Members) responsible for improving animal health worldwide. OIE standards guidelines and recommendations for animal health and zoonoses are internationally recognised by the World Trade Organisation (WTO) as standards for the trade in animals and animal products.

OIE's vision is to improve the Good Governance of Veterinary Services worldwide via an array of actions and activities, including better compliance of international standards, technical and financial support to countries, and alliances with both public and private sector stakeholders.

Linked to this, OIE has progressively developed the PVS Pathway, which is a global continuous process aiming to sustainably improve the compliance of Veterinary Services with OIE international standards. .

OIE is the key organisation for global disease surveillance: OIE Members have a formal obligation to submit information on their animal disease situation, in the most timely and transparent manner. OIE is responsible for providing public access to all data validated through its World Animal Health Information System (WAHIS/WAHID).

Animals play an important role as biosensors for accidental or deliberate releases of infectious agents and toxins, and for emerging diseases. 
The same disease surveillance and intelligence systems that are in place to detect day-to-day occurrences of natural outbreaks, within countries and at national borders, will also detect deliberate and accidental releases.

This approach is consistent with and supported by the OIE's Fifth Strategic Plan (2011-2015) and cuts across all of its six objectives, namely international communication of global animal disease and zoonosis situation; development and implementation of science-based standards and guidelines on prevention, control and eradication of animal diseases, including zoonoses, and safety of international trade in animals and animal products as well as laboratory excellence; ensuring the scientific excellence of information and advice; capacity-building for national Veterinary Services, including their surveillance and response capacities; and strengthening the organisation's influence on policy design, applied research and governance

\subsubsection{The legislative framework for contingency planning in the $\mathrm{EU}$}

Barbara Logar, DVM, European Commission, Directorate -General Health and Consumers

Contingency planning is essential for ensuring the preparedness for a rapid response to the emergency of animal disease outbreaks. It contributes to disease awareness and preparedness and provides Member States with a tool for immediate implementation of control measures at all levels. Contingency planning is deeply rooted in Union animal health legislation, is referred to in the Animal Health Codes of the World Organisation for Animal Health (OIE) and disease specific guidelines for the preparation of such plans are published by the Food and Agriculture Organization of the United Nations.

Specific Union measures laid down for the control of foot-and-mouth disease, classical and African swine fever, avian influenza, Newcastle disease, Bluetongue and African horse sickness also oblige Member States to set up, keep up to date and regularly rehearse disease specific contingency plans.

In case of a serious animal health emergency and based on the horizontal legislation on veterinary controls, the European Commission assists Member States in particular by supplementing the measures implemented in accordance with the disease specific control directives with rapidly adopted protection measures providing additional condi- 
tions aiming at minimising the spread of disease within and into Member States but also to protect neighbouring countries and trade partners and documenting regionalisation where applicable.

Frequent meetings of the Standing Committee of Food Chain and Animal Health (SCFCAH) provide the information on the disease situation to the Member States and thus build trust and confidence between them and foster their cooperation.

Where necessary and requested by a Member State or a neighbouring third country, the Commission may at any time deploy the veterinary emergency team established in the framework of the Animal Health Emergency System maintained by the Directorate-General for Health and Consumers.

According to the motto "Prevention is better than cure," emergency preparedness will occupy an important position in the new EU Animal Health Law, which will based on the existing EU disease control legislation particularly provide for contingency planning, simulation exercises, antigen and vaccine banks, diagnostic reagent banks and veterinary emergency teams.

\subsection{Session II. Contingency planning - Data collection, storage and handling of disease data}

\subsubsection{The IT-sector's views on transmission, collection, storage and distribution of data is disaster situations}

David Aanensen, Lecturer, Faculty of Medicine, Imperial College, London

By use of video the participants of the seminar received information on a smartphone system developed by researchers at the Imperial College London. The smartphone application allows the user to collect and record data, photos and videos and sends this to a central web-based database.

A special programme, EpiCollect, has been developed and designed to assist scientists in the field to analyse their data remotely and map findings without having to return to the laboratory.

The system has been tested in East Africa. EpiCollect allows veterinarians and community animal health workers in the Kajiado district, central Kenya to upload their findings to a central website which plots where diseases are occurring. A wide range of diseases are being moni- 
tored including the zoonotic diseases anthrax and rabies and the devastating livestock diseases: foot-and-mouth disease, East Coast fever, Peste des Petits Ruminants (PRR) and others.

By having a good monitoring system it should make it easier for veterinarians in cooperation with farmers to make arrangement for disease prevention and control including the planning and implementation of vaccination programmes.

The EpiCollect system has been designed for phones running the Android open-source operating system developed by Google and the Open Handset Alliance. A special beta version for the Apple iPhone has also been produced with the aim of making the software available to more people.

The EpiCollect software is free to download and it is hoped that members of the public in the future will help to collect data for scientific projects. Such projects could be to track sightings of migrating birds, a subject of interest for risk assessments and contingency planning within the context of certain poultry diseases.

\subsubsection{Handling of data related to disease outbreaks}

Emma Rose, MA VetMB LLB (Hons), Veterinary Adviser, VLA; the UK

The smooth flow of data during an outbreak is integral to not only ensuring that the appropriate control measures are put in place in a timely manner, but also to provide reassurance about the progress made and whether the disease situation is under control.

Even before disease confirmation accurate data is essential in ensuring that the correct communications about prevention and reducing risk are made and targeted to the relevant audience, be it colleagues, Ministers, the EU or to manage the expectations of the media and inform the farming industry.

Once disease has been confirmed "data" may refer "simply" to what is already known about the susceptible population (locations and numbers of animals), or it may relate specifically to the efforts being put into control the disease such as tracings and zone patrol visits.

Different teams within the control effort and governing authorities overseeing the response, both at national and at international levels will require reports, maps and statistics. All are usually demanded at different frequencies, in different formats, to different levels of detail and often at short notice. Knowing in advance the types of data requests that 
may be received can be helpful to devise suitable IT systems, paperwork forms and staff working instructions, however in the UK's experience each outbreak of disease requires a slightly different approach to the one anticipated and planned for. This often results in extra demand on staff resources to ensure that the data being captured in an outbreak is accurate, up to date and can be readily accessed and in a consistent accurate manner.

Training staff to expect any eventuality encourages flexibility in the control response and data handling processes even under pressure of dealing with simultaneous disease outbreaks such as seen in the UK in 2007.

\subsubsection{The development and use of LEIF for animal health emergencies}

Borje Adolfson, LEIF administrator and developer, the Swedish Board of Agriculture

In an outbreak of contagious animal disease you need to access a management platform quickly. A platform, the headquarters and any other staff involved in the outbreak, need to have access to: shared documents, as well as mailboxes and task lists. It is also important that all actions that take place will be noted in a logbook. This is especially important early in the start-up phase, because it often can be a bit "chaotic," with new staff and no or very little routines established.

LEIF - LEading and Information system For jordbruksverket- is a web platform that the Swedish Board of Agriculture has developed for use in the management of crisis. In the presentation during the seminar, the main features of the LEIF will be presented.

LEIF use a secure login, in two steps. First with username and password, then authorisation through a SMS-code sent to your mobile phone. This means that the system has a high information classification and it allows us to store all the documentation around an outbreak directly on the site. LEIF also can be administered locally in the field, which speeds up the process to get started in the outbreak tracing. To work in crises often means: temporary staff and staff who often comes and goes. In the same moment a person is given access to the LEIF-system, he/she also has access to the information and the tools needed to manage the task. Features we think are very important for a web-based management system.

Local administrator: LEIF is administered locally in the field and it's easy to add new users. It is also easy to create new working teams and 
units in the system. The system automatically creates new mailboxes etc. Furthermore it adds the appropriate access permissions by default values.

LEIF documents: A default folder-structure with all working papers. Access to documents can be regulated by access-rights, all documents have version control and it is always possible to recover documents deleted by mistake. In addition, all modifications are registered in the log book. There you can see if a document is newly created or modified.

LEIF e-mail: LEIF has an integrated mail system. The e-mail is associated with a function, not a person. E-mail is coming to the working team you belong to, not to a specific person. The same principle applies to "tasks."

LEIF Tasks: The working team or the unit tasks are listed with the history by threads. It is easy for the headquarters to follow a task during execution of it. Data also uses colour-codes: red, yellow or green. Depending on whether the task is delayed, pending or if the task already is completed. Everything to make a simple overview

LEIF Log: The log traces everything that happens in LEIF: incoming and outgoing e-mail, tasks who are completed and if any new documents are created etc. This makes it easier for the headquarters to follow progress of the work during the outbreak. Everything is logged, tracked, gathered and is easier to follow up afterwards.

LEIF makes the management of an outbreak to get started more quickly, the system ensures the staff to log things that would otherwise be forgotten. All data are linked to a function or a working team and not to a person. All documentation and information is gathered in one place. We think that LEIF give us a good traceability and a good tool to use in management of crises or outbreak of contagious animal diseases. All your need for the start-up phase is a laptop and an Internet connection. 


\subsection{Session III. Contingency planning for the next decade - the veterinarian in the private sector, equipment and financing}

\subsubsection{Contingency planning and veterinarians in private practices providing services to the livestock industry}

Walter Winding, Dr. med. vet., Federations of Veterinarians in Europe

The wide scopes of veterinary education as well as professional and ethical responsibilities towards both, animals and humans involve veterinarians in the battle against emerging diseases by a crucial role. Due to historical developments and habits the veterinary services were very often just limited to actions of state veterinary officers.

The experience of recent catastrophic outbreaks has shown that a well prepared partnership between the governmental and private sector, based on recognition of each other's role and contribution is the key for a successful prevention and also management of a crisis! In addition to their professional skills veterinary practitioners have a valuable experience and knowledge of local causally connections and habits through their daily contact to animals and their holders.

Based on a profound veterinary education an additional training and continuing education with regard to emerging diseases, crisis management and communication is an important condition for all involved partners.

To enable a rapid and coordinated alert, calling and action of the different partners as well as to secure personnel resources out of the private sector for governmental tasks, contractual contacts and preparations between governmental and private representative bodies will be crucial! Facing the development that driven by financial reasons governmental resources are more and more reduced and many tasks outsourced, a harmonised interaction between public and private sector will be become inevitable in the future! 


\subsubsection{Review of equipment available for use in the field during major disease outbreaks}

Edvins Olsevskis, DVM, Deputy Director of Veterinary Surveillance Department. Food and Veterinary Service, Latvia

Availability of equipment to be used to control disease outbreak is a very important part of contingency planning. Different measures during the outbreak control such as animal killing and destruction, cleaning and disinfection of infected premises and transport requires involvement of specific equipment (including IT systems for communication and reporting) in a short time. Several options are used by veterinary services of Nordic-Baltic countries to make emergency equipment available for use during disease outbreaks:

- Owning (purchase and maintenance).

- Rent (agreements set with private companies).

- State emergency reserve (state service responsible for maintenance of equipment to be used for management of different emergency cases including disease outbreaks).

- International agreements and memorandums on emergency reserve.

Main technical requirements for emergency equipment are:

- available for use in a short period of time

- availability to use in a field conditions (mobile, self-supporting, compact etc.,)

- large capacity, capable for use long-lasting - to control outbreak rapidly

- easy to clean and disinfect (to prevent spread of disease agent)

- in good technical condition (well maintained and regularly checked)

- skilled and trained stuff to operate equipment and permanent technical assistance.

Availability of emergency equipment at local level largely depends on animal population (species, size and density) in a region. General equipment is absolutely necessary for local veterinary services to manage small outbreaks or to start eradication measures before specific larger equipment becomes available.

Veterinary services are mainly responsible for availability of emergency equipment at the national level. The decision on type and number of emergency equipment necessary has to be taken by veterinary ser- 
vices after risk assessment, careful consideration of animal population and density and resources available.

International collaboration on exchange of emergency equipment is welcome, however there are several practical issues that need to be considered and can make this process complicated.

\subsubsection{The interaction between the farmer, the livestock industry and official authorities during disease emergencies - How to succeed?}

Karsten Aagaard, DVM, Aagaard Consulting, Denmark

\section{Background}

Europe had outbreaks of Bluetongue in 2006-2010. Denmark had outbreaks on 16 farms in total in 2007 and 2008. Denmark became free status $1^{\text {st }}$ January 2011. Many animals were vaccinated in 2008. The interaction between the farmers, the livestock industry and official authorities during the outbreak of the disease in Denmark was a success. All groups of interest in Denmark followed the disease moving from South Europe up north and in the beginning nobody had seen the disease would reach that north as Denmark. In Denmark the first cases were founded in 2007. Other Nordic countries became infected by Bluetongue virus as well.

The official authorities decided to vaccinate against the disease and overnight a vaccination program had to be schemed. Lack of vaccines required risk zones of Denmark to be vaccinated in different times of the year.

\section{Objective}

To avoid an outbreak of Bluetongue in Denmark.

\section{Method}

All groups of interest which included The Danish Ministry of Agriculture, Food and Fisheries, The Danish Veterinary Association and farmers dealing with cattle, sheep and goats represented by The Danish Cattle Federation negotiated how to organize the vaccination campaign. Veterinarians, vaccination teams and the farmers themselves did all the vaccination.

\section{Results}

Well organized programs during the year resulted in a very high vaccinating rate for beef, dairy, sheep and goats. 


\section{Conclusions}

Acknowledgement of the need of cooperation between all groups of interest let to agreements and the needed interactions between the farmer, the livestock industry and official authorities. Vaccination of all cattle, sheep and goats in selected zones were done according to the disease situation as such and vaccines available.

\subsubsection{Financing of measures related to preventing, controlling and eradicating infectious diseases in livestock, poultry and live fish. Who shall pay?}

Stig Mellergaard, DVM, Danish Veterinary and Food Administration

According to the EU Animal Health Strategy (2007-2013) the key concept is "Prevention is better than cure." So far, problems with notifiable diseases have been a case for the veterinary authorities of the Member States. This new concept implies that the main responsibility for the prevention of notifiable animal diseases will be in the hands of the individual farmer.

Disease prevention at farm level has so far not been dealt with as a Community matter so the costs for such measures has been borne by the individual farmers as a normal part of their biosecurity measures. The Commission has considered the possibility of finding a solution where investments in biosecurity on farm level could receive co-financing via some of the existing agricultural support systems.

The responsibility for disease control and eradication has been and will still be on the competent veterinary authorities. However, the financing of the cost involved in these activities have in most Member States been made by the national veterinary authorities while in other Member States different models for shared responsibility has been developed. In the Animal Health Strategy it is proposed that the responsibility and as well as the costs should be shared between the individual farmer and/or the agricultural industry and the national authorities.

The Commission has presented some considerations on the overall principles for a cost sharing model and for co-financing of veterinary crisis on Member State level but these have met some opposition from Member States. However, some Member States have already established different systems for cost sharing and these systems together with the Commissions considerations will be presented for future inspiration. 


\title{
2.4 Session IV: Bio-terrorism and contingency planning
}

\subsubsection{Bio-terrorism and biological contingency planning}

\author{
Rickard Knutsson, PhD., the Swedish Board of Agriculture
}

This oral presentation highlights (i) biowarfare and bioterrorism through the ages (ii) microbes for potential biological warfare and (iii) present status and ongoing activities concerning bioterrorism contingency plans. Bacteria, virus, toxins and parasites may be used as biological weapons and deliberately spread through feed, food and water to cause fear and panic. Biowarfare and bioterrorism through the ages have a long history. The early use of biowafare was used before $600 \mathrm{BC}$ without. However it was during World War I and World War II, that it was used in a broader scale and after World War II some countries had offensive biowarfare programmes. After $9 / 11$ and the anthrax letters in the US, bioterrorism concerns have become a global issue. There are many agents that are listed as bioterrorism agents, such as on the CDC/USDA select agent lists and the Australia group list. Bio- and agro terrorism is probably among the most inter-sectoral and international challenges among CBRN threats and contingency plan is crucial for both covert and overt incidents. An early response related to a covert incident, which is characterized by an unannounced release, will be driven by public and animal health organizations. An overt incident is however characterized by the fact that the perpetrator announces responsibility and the response will therefore be driven by law enforcement. To set up preparedness will therefore require a multidisciplinary network between various sectors. Vulnerability assessment is crucial to perform concerning bio-terrorism contingency planning. There are much vulnerability within the agriculture and the food security chain. For instance, the agriculture is extremely important for many countries economy and animal diseases can be found in the environment. The response to disease outbreaks are in general made from a natural disease outbreak and not from deliberate man-made disease outbreaks. Forensic response plans must be integrated into existing contingency plans. 



\section{Conclusions and recommendations}

The Nordic -Baltic seminar on Contingency planning for the next Decade was held in Helsinki, Finland from 19-20 September 2012.

The objectives of the seminar were to elucidate the following issues:

- Contingency planning at international and at national level.

- Challenges facing veterinary administrations at central, regional and local level and livestock industries in contingency planning.

- Legislation and contingency planning.

- Desirable Databases - software and hardware - for contingency planning and implementation of disease control measures.

- Globalization and animal health threats.

The seminar had focus on needs and methods for preparation, up-dating and testing contingency plans in the area of Animal Health.

The first day of the seminar highlighted the potential future livestock production systems, the main elements and challenges within the area of contingency planning at National and Global level and the legislative framework for contingency planning at the EU level. The second day had focus on collection, storage and distribution of data during disease emergency situation, the importance of services provided by private practitioners to the livestock sector, equipment for use during major disease outbreaks, the interaction between the farmer, the livestock industry and official authorities during disease emergencies, financial matters and certain aspects of bio-terrorism.

The seminar showed the importance of having constructive dialogues and close cooperation between scientists, legislators, private and official veterinarians, administrators, the livestock industry and managers involved in contingency planning. The participation of representatives from World Organisation for Animal Health (OIE), the European Commission (EC), the Federation of Veterinarians of Europe (FVE) and the UK Veterinary Services provided valuable information on disease control measures applied outside the Nordic-Baltic countries. The partici- 
pants of the seminar accepted the views that contingency planning in the area of animal health should cover:

- The pre-epidemic period ("Peace time").

- The epidemic period, ("War time").

- The post-epidemic period (Time of rehabilitation).

The activities to be carried out during the three different periods are closely related but nevertheless require different training programmes to ensure the presence of adequate skills.

The presentations made during the seminar provided an excellent basis for a valuable exchange of views between the experts from the participating countries. The outcome of the discussions is reflected in the recommendations listed below.

\subsection{Recommendations}

- Biosecurity refers to the prevention of disease causing agents entering or leaving any place where farm animals are present. A number of biosecurity measures are very well known but shortcoming in implementation of the measures have been noticed. A common understanding of the concept among farmers seems to be lacking and need to be established.

The Nordic Baltic Veterinary Contingency Group has scheduled a Seminar on Biosecurity to be held in 2014 in Sweden.

It is recommended that the N-B VCG for the scheduled Biosecurity seminar takes into account topics related to:

- Scientific aspects

- Motivation for and ownership of biosecurity plans

- Training of involved partners

- Implementation of biosecurity plans

- Social aspects

- Communication

- Economics

- Standards, protocols and legislation. 
- Contingency plans shall be considered as living documents and regularly up-dated to ensure that they are adequate and take into account changing animal husbandry systems, technological developments, changing trade patterns, changing disease situations, the organisations of stakeholders and legislative amendments. The conduct of simulation exercise is an important tool for assessing and up-dating of contingency plans.

It is recommended that the terminology related to simulation exercises in the area of animal health is reviewed at international level and that a manual covering the preparation and implementation of different kind of simulation exercises are being developed.

- The implementation of disease control and eradication programmes calls for a close cooperation - partnership - between the farmer, the veterinarian in private practise and the official veterinarian; a partnership based on recognition of each other's role and contribution to successful disease prevention and control. Another important form for partnerships in contingency planning, which could be highlighted is the "Memorandum of Understanding on an Animal Health Emergency Reserve" adopted by the Veterinary Administrations of the Nordic and Baltic countries; a Memorandum established with the aim to strengthen the collaborative relationship for the purpose of fighting the spread of serious animal diseases.

It is recommended that the N-B VCG explores ways to encourage further development and implementation of good working relationship, cooperation and communication between the partners.

- The participants of the seminar recognised the importance of databases for the collection storage, analysis and distribution of information during implementation of disease surveillance, control and eradication programmes.

It is recommended that the N-B VCG encourages the sharing of ITprogrammes and software available within the Nordic-Baltic countries. 
- Bioterrorism with deliberate release of serious pathogenic agents is a potential threat which, so far, has not been used in Europe. The livestock sector may be a potential target. Nevertheless, the participants were informed about microbial agents having a potential use in bioterrorism, the need for multidisciplinary network and the content of biological contingency plans.

It is recommended that in view of the great vulnerability of livestock to bioterrorism the threat should not be overlooked by the veterinary profession.

\subsection{Acknowledgements}

The organizers of the Nordic-Baltic seminar on Contingency planning for the next decade would like to express their thanks to the Nordic Council of Ministers for the political support and the financial support made available for the preparation, implementation and valuation of the seminar.

The support made it possible for the national experts from the Nordic and Baltic countries to meet with representatives of international organisations and discuss topics of mutual interest within the context of contingency planning.

A special thank shall be addressed to all the speakers for the well prepared presentations, the chairmen managing competently the different sessions and to all the participants for active contributions to the success of the seminar. It is our hope that many valuable networks have been established for the future work concerning animal disease preparedness and contingency planning.

The seminar would not have conducted with success without the valuable support given by Dr. Matti Aho, the Chief Veterinary Officer of Finland and the staff of the Finnish Food and Safety Authority EVIRA. 


\section{Sammendrag}

Det Nordisk-Baltiske seminar omhandlende veterinærberedskabsplanlægning i de kommende tiår, blev afholdt i Helsingfors, Finland fra den 19-20 september i 2012.

Formålet med seminaret var at belyse følgende emner:

- Beredskabsplanlægning på internationalt og på nationalt niveau.

- De udfordringer som de veterinære myndigheder på central, regional og lokal plan og husdyr sektoren, står overfor i forbindelse med beredskabsplanlægning.

- Lovgivning og beredskabsplanlægning.

- Ønskelige databaser - software og hardware - til brug for beredskabsplanlægning og gennemførelse (virkeliggørelse) af sygdomsbekæmpelsesforanstaltninger.

- Globalisering og trusler mod dyresundhed.

Endvidere havde seminaret fokus på behovet for og metoder til udarbejdelse, opdatering og afprøvning af veterinære beredskabsplaner

Seminaret belyste på den første dag: potentielle fremtidige husdyrproduktions metoder, hovedelementerne og udfordringer vedrørende beredskabsplanlægning på nationalt og globalt niveau, og de lovgivningsmæssige rammer for beredskabsplanlægning indenfor EU. På seminarets 2. dag var der fokus på: indsamling, opbevaring og distribuering af data i sygdomskrise situationer; betydning af privat praktiserende dyrlægers ydelser til husdyrsektoren; udstyr til brug under store sygdomsudbrud; samarbejdet imellem landmand, landbrugsorganisationer og de offentlige myndigheder i krise situationer; økonomiske forhold og visse aspekter af bioterrorisme.

Udbyttet af seminaret omfattede:

- Konstruktive dialoger.

- Tæt samarbejde imellem videnskabsfolk, lovgivere, private og offentlige ansatte dyrlæger, administratorer, husdyrsektoren, og ledere involveret i beredskabsplanlægning. 
Deltagere i seminaret som repræsenterede: Verdensorganisationen for dyresundhed (OIE), Europa Kommissionen (EF), Sammenslutningen af dyrlæger i Europa (FVE) og fra veterinære myndigheder i UK gav værdifulde oplysninger om sygdomsbekæmpelsesforanstaltninger, som anvendes udenfor de Nordiske og Baltiske lande. Deltagerne i seminaret kunne tilslutte sig, at det veterinære beredskab skal omfatte:

- Den præ-epidemiske periode ("Fredstid").

- Den epidemiske periode ("Krigstid").

- Den post-epidemiske periode (Tiden til brug for rehabilitering).

Alle aktiviteter, som bliver udført i de 3 forskellige perioder, er tæt relaterede; men ikke desto mindre kræver forskellige træningsprogrammer for at sikre tilstedeværelse af optimale færdigheder.

De indlæg, som blev givet på seminaret og under panel diskussionen omhandlende smittebeskyttelse, gav et glimrende grundlag for værdifuld udveksling af synspunkter og drøftelser imellem mødedeltagerne. I lyset af disse drøftelser blev der vedtaget 5 anbefalinger, som omhandlede aspekter af:

- Smittebeskyttelse.

- Beredskabsøvelser.

- Samarbejde i beredskabsplanlægning.

- It-programmer og software.

- Bioterrorisme.

Den fulde ordlyd af anbefalingerne er givet afsnittet, der omtaler konklusioner og anbefalinger. 


\section{Annexes}

\subsection{Annex 1: The programme}

Seminar on Contingency Planning for the next Decade. The Nordic-Baltic veterinary Contingency Group.

\section{9-20 September 2012, Helsinki, Finland.}

\begin{tabular}{|c|c|}
\hline 10:30-12:00 & Lunch and Registration of Participants \\
\hline \multirow[t]{3}{*}{ 12:00 } & Opening session \\
\hline & Dr. Matti Aho, Chief Veterinary Officer of Finland \\
\hline & Dr. Audur Lilja Arnthorsdottir, Chairman of the Nordic-Baltic Veterinary Contingency Group. \\
\hline \multirow[t]{2}{*}{$12: 20$} & Session I: Contingency planning at international and national level \\
\hline & Chair: Dr. Sirpa Kiviruusu, Finland \\
\hline \multirow[t]{2}{*}{$12: 20$} & The future livestock production - trends, challenge, threats and opportunities \\
\hline & Dr. Jan Dahl, Chief Advisor of the Danish Agriculture and Food Council \\
\hline \multirow[t]{2}{*}{ 13:05 } & What is contingency planning in the area of animal health? \\
\hline & Dr. Jørgen M. Westergaard, ADC-Consult, Denmark \\
\hline 13:40 & Coffee break \\
\hline \multirow[t]{3}{*}{$14: 10$} & The OIE and Global Contingency Planning \\
\hline & Dr. Alain Dehove, Coordinator of the OIE World Animal Health and Welfare Fund, the World \\
\hline & Organisation for Animal health, OIE, Paris \\
\hline \multirow[t]{2}{*}{ 14:55 } & The legislative framework for contingency planning in the EU \\
\hline & $\begin{array}{l}\text { Dr. Barbara Logar, Legislative Veterinary Officer, Directorate - General Health and Consum- } \\
\text { ers, European Commission, Bruxelles }\end{array}$ \\
\hline \multirow[t]{2}{*}{ 15:40 } & Theme Panel discussion on Biosecurity \\
\hline & Discussion leader: Riitta Maijala, Unit leader, Finish Food Safety Authority \\
\hline $16: 40$ & Closing of the day \\
\hline $19: 00$ & Seminar dinner \\
\hline
\end{tabular}




\begin{tabular}{|c|c|}
\hline 09:00 & $\begin{array}{l}\text { Session II: Contingency planning - Data collection, storage and handling of disease data } \\
\text { Chair: Dr. Egidiijus Pumputis, Lithuania }\end{array}$ \\
\hline 09:00 & $\begin{array}{l}\text { The IT-sector's views on transmission, collection, storage and distribution of data in } \\
\text { Disaster situations } \\
\text { Dr. David Aanesen, Faculty of medicine, Imperial College, London }\end{array}$ \\
\hline 09:45 & $\begin{array}{l}\text { Handling of data related to disease outbreaks } \\
\text { Dr. Emma Rose, Veterinary Adviser, Animal Health and Veterinary Laboratories Agency (VLA), UK }\end{array}$ \\
\hline $10: 30$ & $\begin{array}{l}\text { The development and use of LEIF for animal health emergencies } \\
\text { Dr. Borje Adolfsson, Swedish Board of Agriculture }\end{array}$ \\
\hline $10: 45$ & Discussion related to the presentations in session II \\
\hline $11: 00$ & Lunch \\
\hline $12: 00$ & $\begin{array}{l}\text { Session III: Contingency planning for the next decade - the veterinarian in the private sector, } \\
\text { equipment and financing } \\
\text { Chair: Dr. Siri Løtvedt, Norway }\end{array}$ \\
\hline $12: 00$ & $\begin{array}{l}\text { Contingency planning and veterinarians in private practice providing services to the livestock } \\
\text { industry } \\
\text { Dr. Walter Winding, Former President of the Federation of Veterinarians (FVE) in Europe }\end{array}$ \\
\hline $12: 45$ & $\begin{array}{l}\text { Review of equipment available for use in the field during major disease outbreaks } \\
\text { Dr. Edvins Olsevskis, Food and Veterinary Services, Latvia }\end{array}$ \\
\hline $13: 00$ & $\begin{array}{l}\text { The interaction between the farmer, the livestock industry and official authorities during } \\
\text { disease emergencies - How to succeed? } \\
\text { Dr. Karsten Aagaard, Aagaard Consulting, Denmark }\end{array}$ \\
\hline $13: 20$ & $\begin{array}{l}\text { Financing of measures related to preventing, controlling and eradicating infectious diseases } \\
\text { in livestock, poultry and farmed fish. Who shall pay? } \\
\text { Dr. Stig Mellergaard, Chief Advisor, Danish Food and veterinary Administration }\end{array}$ \\
\hline 14:05 & Discussions related to the presentations in session III \\
\hline $14: 20$ & Coffee break \\
\hline $14: 40$ & $\begin{array}{l}\text { Session IV: Bio-terrorism and contingency planning } \\
\text { Chair: Dr. Elisabet Lindal, Sweden }\end{array}$ \\
\hline $14: 40$ & $\begin{array}{l}\text { Bio-terrorism and biological contingency planning } \\
\text { Dr. Richard Knutson, AniBio Threat, Sweden }\end{array}$ \\
\hline $15: 10$ & Discussions related to the presentations in session IV \\
\hline $15: 30$ & Closing and recommendations of the seminar \\
\hline
\end{tabular}




\subsection{Annex 2. The Organizing Committee}

The Organizing Committee established by the Nordic-Baltic Veterinary Contingency Group for the preparation and implementation of the seminar on Contingency Planning for the next Decade consisted of:

- Sirpa Kiviruusu, EVIRA, Finland.

- Siri Løtved, Norway.

- Edvins Olsevskis, Latvia.

- Audur Lilja Arnthorsdottir, Iceland.

- The work of the Committee was in the Technical Secretariat assisted by Hannele Kohtala, Office Secretary, EVIRA. 


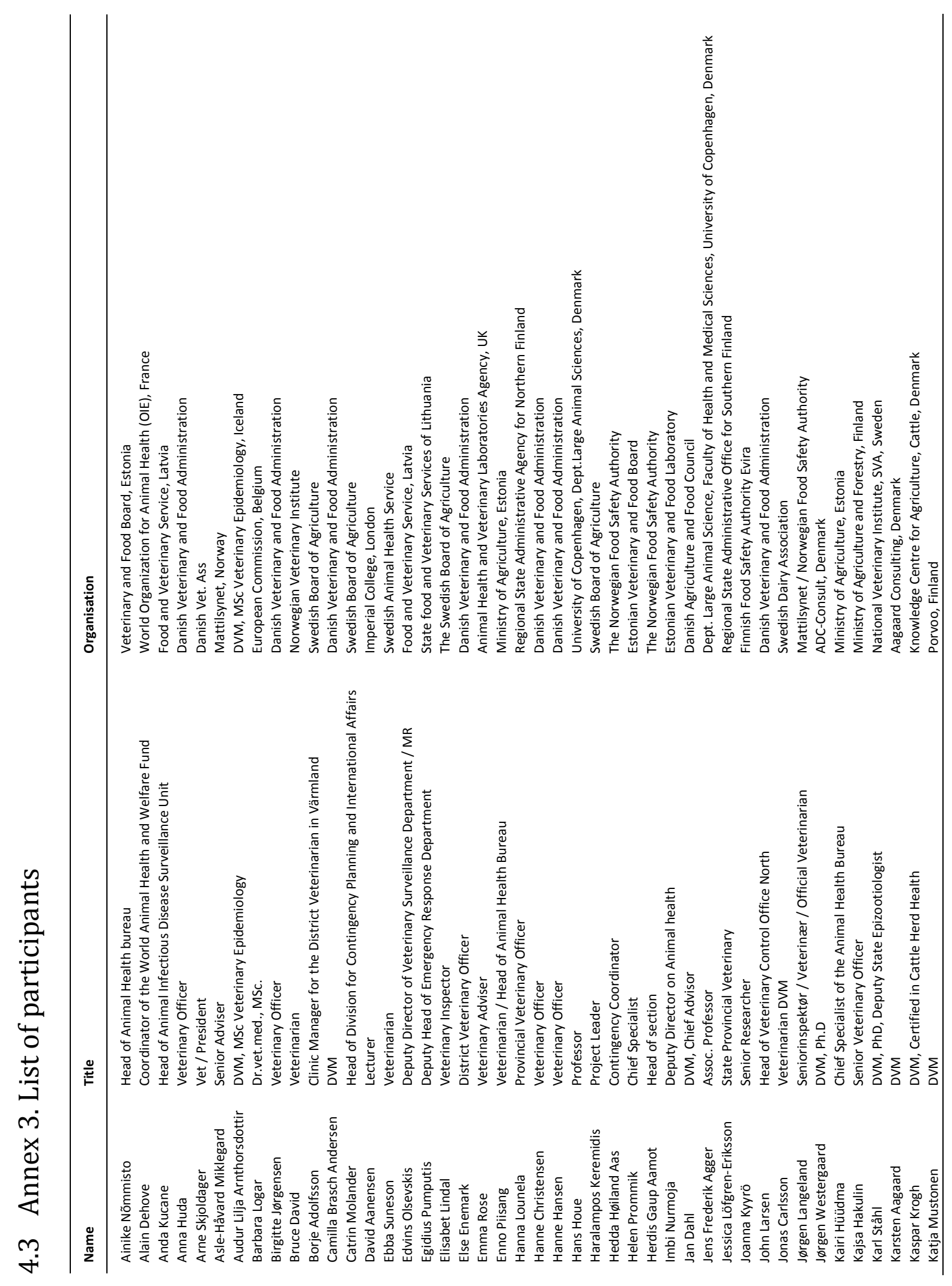




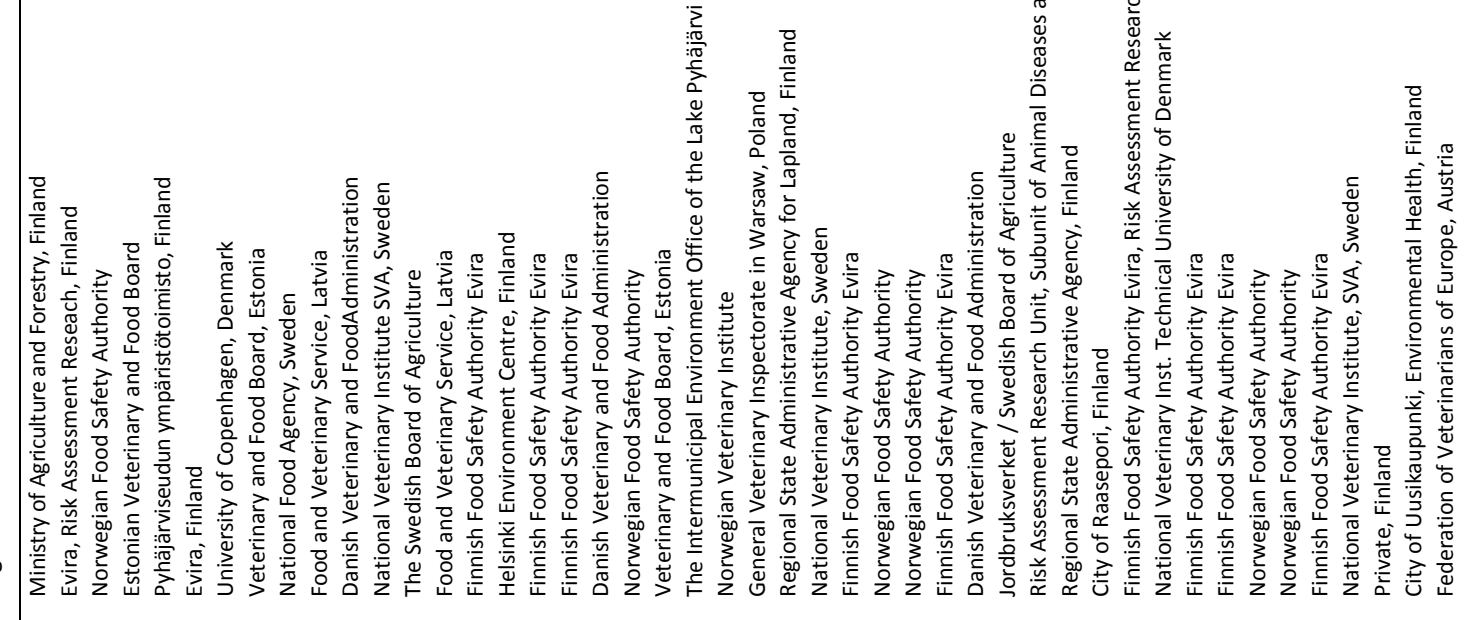
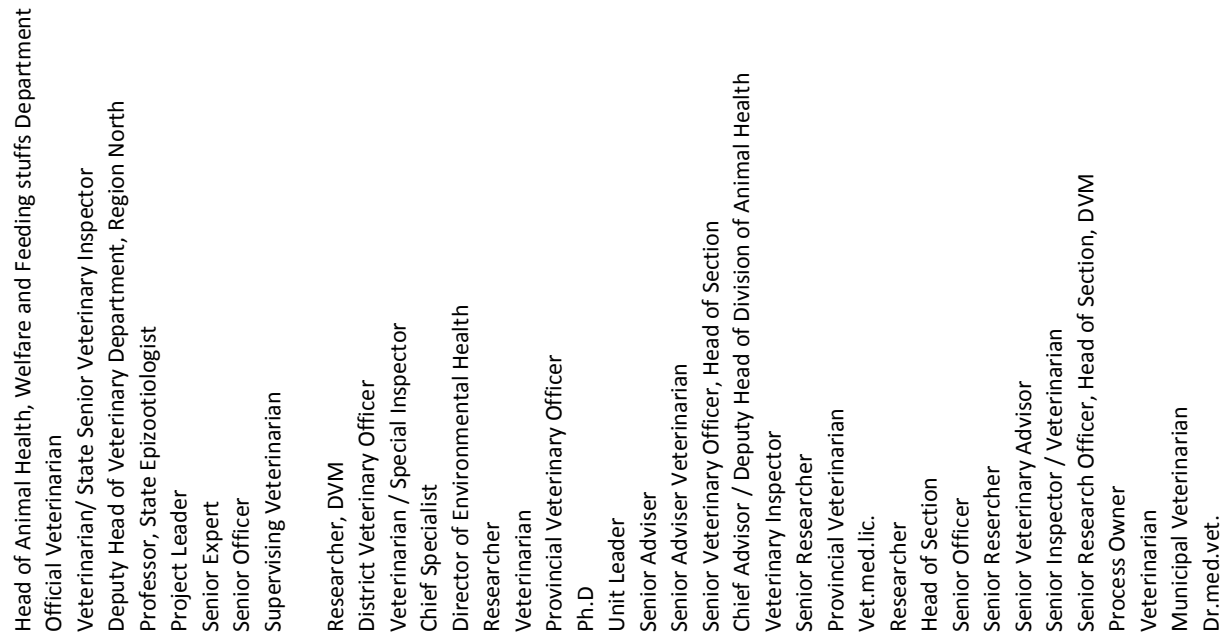

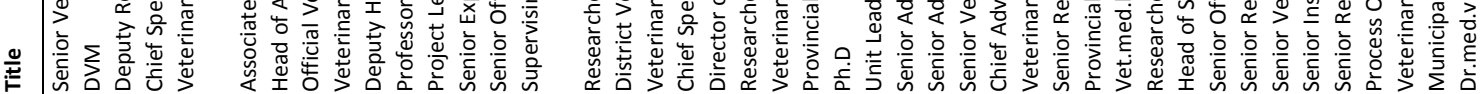

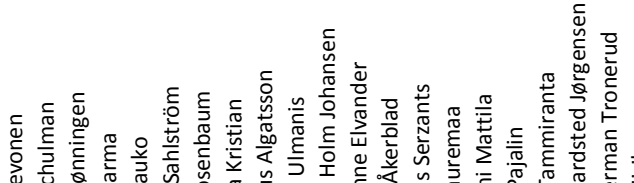

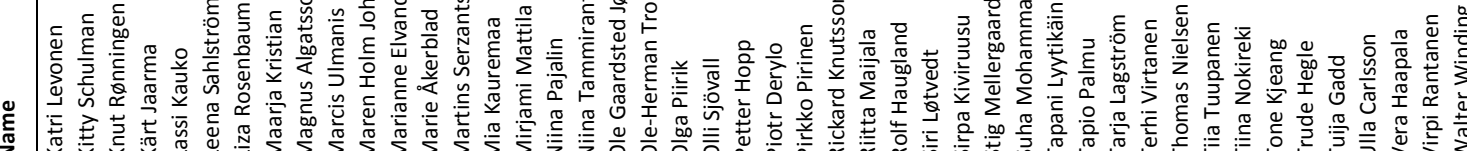

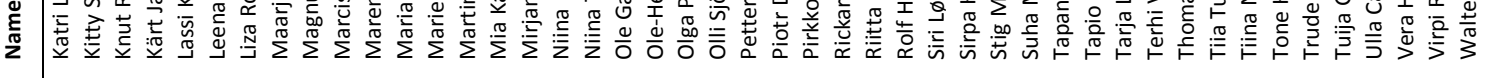




\subsection{Annex 4. Evaluation}

The evaluation scale to be used during the evaluation was: $1=$ poor and $5=$ excellent.

\begin{tabular}{|c|c|c|c|c|c|c|}
\hline General questions & 1 & 2 & 3 & 4 & 5 & $\begin{array}{r}\text { Not } \\
\text { relevant }\end{array}$ \\
\hline $\begin{array}{l}\text { Did the seminar meet your expectations in rela- } \\
\text { tion to networking and sharing experiences }\end{array}$ & & 1 & 5 & 15 & 6 & \\
\hline $\begin{array}{l}\text { Did you feel you had the necessary prerequisites } \\
\text { (knowledge skills etc) to be able to benefit from } \\
\text { the seminar }\end{array}$ & & & 2 & 13 & 12 & \\
\hline $\begin{array}{l}\text { The choice of topics for sessions were topical and } \\
\text { relevant }\end{array}$ & & 1 & 6 & 12 & 8 & \\
\hline $\begin{array}{l}\text { How did you find the supplied material, hand outs, } \\
\text { etc. }\end{array}$ & & & 9 & 9 & 4 & 5 \\
\hline $\begin{array}{l}\text { The seminar has improved my knowledge of the } \\
\text { "contingency planning" concept }\end{array}$ & & 3 & 8 & 13 & 3 & \\
\hline Over all, how did you find the seminar & & & 2 & 17 & 6 & \\
\hline
\end{tabular}

Replies: 27. Replies question 6: 25 .

\begin{tabular}{|c|c|c|c|c|c|c|}
\hline General questions & 1 & 2 & 3 & 4 & 5 & $\begin{array}{r}\text { Not } \\
\text { relevant }\end{array}$ \\
\hline $\begin{array}{l}\text { Did the seminar meet your expectations in rela- } \\
\text { tion to networking and sharing experiences }\end{array}$ & & 3.70 & 18.52 & 55.56 & 22.22 & \\
\hline $\begin{array}{l}\text { Did you feel you had the necessary prerequisites } \\
\text { (knowledge skills etc) to be able to benefit from } \\
\text { the seminar }\end{array}$ & & & 7.41 & 48.15 & 44.44 & \\
\hline $\begin{array}{l}\text { The choice of topics for sessions were topical and } \\
\text { relevant }\end{array}$ & & 3.70 & 22.22 & 44.44 & 29.63 & \\
\hline $\begin{array}{l}\text { How did you find the supplied material, hand outs, } \\
\text { etc. }\end{array}$ & & & 33.33 & 33.33 & 14.81 & 18.52 \\
\hline The seminar has improved my knowledge of the & & 11.1 & 29.63 & 48.15 & 11.11 & \\
\hline "contingency planning" concept & & 1 & & & & \\
\hline Over all, how did you find the seminar & & & 8 & 68 & 24 & \\
\hline
\end{tabular}




\begin{tabular}{|c|c|c|c|c|c|c|}
\hline & 1 & 2 & 3 & 4 & 5 & $\begin{array}{r}\text { Not } \\
\text { relevant }\end{array}$ \\
\hline \multicolumn{7}{|c|}{ Session I. Contingency planning at international and national level } \\
\hline $\begin{array}{l}\text { The future livestock production - trends, chal- } \\
\text { lenge, threats and opportunities }\end{array}$ & & 1 & 3 & 12 & 14 & \\
\hline $\begin{array}{l}\text { What is contingency planning in the area of animal } \\
\text { health? }\end{array}$ & & 1 & 2 & 14 & 13 & \\
\hline The OIE and Global Contingency Planning & 1 & 8 & 9 & 11 & 1 & \\
\hline $\begin{array}{l}\text { The legislative framework for contingency planning } \\
\text { in the EU }\end{array}$ & & & 9 & 13 & 8 & \\
\hline Theme panel discussion on biosecurity & & & 8 & 12 & 6 & 2 \\
\hline \multicolumn{7}{|c|}{ Session II. Contingency planning - Data collection, storage and handling of disease data } \\
\hline $\begin{array}{l}\text { The IT-sector's views on transmission, collection, } \\
\text { storage and distribution of data in disaster situations }\end{array}$ & & 5 & 6 & 13 & 6 & \\
\hline Handling of data related to disease outbreaks & & 1 & 4 & 12 & 13 & \\
\hline $\begin{array}{l}\text { The development and use of LEIF for animal health } \\
\text { emergencies }\end{array}$ & & 5 & 17 & 4 & 3 & \\
\hline \multicolumn{7}{|c|}{$\begin{array}{l}\text { Session III. Contingency planning for the next decade - the vetrinarian in the private sector, equipment and } \\
\text { financing }\end{array}$} \\
\hline $\begin{array}{l}\text { Contingency planning and veterinarians in private } \\
\text { practices providing services to livestock industry }\end{array}$ & 1 & 2 & 8 & 15 & 4 & \\
\hline $\begin{array}{l}\text { Review of equipment available for use in the field } \\
\text { during majos disease outbreaks }\end{array}$ & 1 & 2 & 13 & 12 & 2 & \\
\hline $\begin{array}{l}\text { The interaction between the farmer, the livestock } \\
\text { industry and official authorities during disease } \\
\text { emergencies - How to succeed? }\end{array}$ & & 3 & 16 & 7 & 4 & \\
\hline $\begin{array}{l}\text { Financing of measures related to preventing, } \\
\text { controlling and eradicating infectious diseases in } \\
\text { livestock, poultry and farmed fish. Who shall pay? }\end{array}$ & & 1 & 5 & 16 & 7 & \\
\hline \multicolumn{7}{|l|}{ Session IV. Bio-terrorism and contingency planning } \\
\hline Bio-terrorism and biological contingency planning & & 1 & 7 & 10 & 6 & \\
\hline
\end{tabular}




\begin{tabular}{|c|c|c|c|c|c|c|}
\hline & 1 & 2 & 3 & 4 & 5 & $\begin{array}{r}\text { Not } \\
\text { relevant }\end{array}$ \\
\hline \multicolumn{7}{|c|}{ Session I. Contingency planning at international and national level } \\
\hline $\begin{array}{l}\text { The future livestock production - trends, chal- } \\
\text { lenge, threats and opportunities }\end{array}$ & & 3.33 & 10 & 40 & 46.67 & \\
\hline $\begin{array}{l}\text { What is contingency planning in the area of animal } \\
\text { health? }\end{array}$ & & 3.33 & 6.67 & 46.67 & 43.33 & \\
\hline The OIE and Global Contingency Planning & 3.33 & 26.67 & 30 & 36.67 & 3.33 & \\
\hline $\begin{array}{l}\text { The legislative framework for contingency plan- } \\
\text { ning in the EU }\end{array}$ & & & 30 & 43.33 & 26.67 & \\
\hline Theme panel discussion on biosecurity & & & 28.57 & 42.86 & 21.43 & 7.14 \\
\hline \multicolumn{7}{|c|}{ Session II. Contingency planning - Data collection, storage and handling of disease data } \\
\hline $\begin{array}{l}\text { The IT-sector's views on transmission, collection, } \\
\text { storage and distribution of data in disaster situa- } \\
\text { tions }\end{array}$ & & 16.67 & 20 & 43.33 & 20 & \\
\hline Handling of data related to disease outbreaks & & 3.33 & 13.33 & 40 & 43.33 & \\
\hline $\begin{array}{l}\text { The development and use of LEIF for animal health } \\
\text { emergencies }\end{array}$ & & 17.24 & 58.62 & 13.79 & 10.34 & \\
\hline \multicolumn{7}{|c|}{$\begin{array}{l}\text { Session III. Contingency planning for the next decade - the vetrinarian in the private sector, equipment and } \\
\text { financing }\end{array}$} \\
\hline $\begin{array}{l}\text { Contingency planning and veterinarians in private } \\
\text { practices providing services to livestock industry }\end{array}$ & 3.33 & 6.67 & 26.67 & 50 & 13.33 & \\
\hline $\begin{array}{l}\text { Review of equipment available for use in the field } \\
\text { during majos disease outbreaks }\end{array}$ & 3.33 & 6.67 & 43.33 & 40 & 6.67 & \\
\hline $\begin{array}{l}\text { The interaction between the farmer, the livestock } \\
\text { industry and official authorities during disease } \\
\text { emergencies - How to succeed? }\end{array}$ & & 10 & 53.33 & 23.33 & 13.33 & \\
\hline $\begin{array}{l}\text { Financing of measures related to preventing, } \\
\text { controlling and eradicating infectious diseases in } \\
\text { livestock, poultry and farmed fish. Who shall pay? }\end{array}$ & & 3.45 & 17.24 & 55.17 & 24.14 & \\
\hline \multicolumn{7}{|l|}{ Session IV. Bio-terrorism and contingency planning } \\
\hline Bio-terrorism and biological contingency planning & & 4.17 & 29.17 & 41.67 & 25 & \\
\hline
\end{tabular}




\subsubsection{Complementary comments to evaluation form}

\section{Comments (in particular on points, where your answer was}

negative)

- OIE: could do better.

- The OIE-presentation was too general and mostly about OIE. Too little linked towards contingency planning. I prefer a live presentation and not Skype presentation.

- It was difficult to hear some of the speakers, and in particular the persons asking questions.

- Sometimes difficult to hear speakers and questions. A couple of coffee breaks would be welcome!

- A lot of focus on Danish economics, production systems, success stories. It had been very interesting to get information from other countries as well i.e. the Baltic countries.

- Good with longer talks rather than short speaks and more speakers!

- Session IV: the speaker could have been better informed on the Nordic situation.

- Very well organized! Thank you!

\section{What was the best part of the seminar?}

- Emma Rose's lecture - shoul have had more time!

- part III, due to discussion between the private sector and governmental.

- The first three sessions on contingency planning.

- Getting ideas for IT system usage, implementation.

- Barbara Logar.

- The presentation by Emma Rose.

- All themes were very interesting. Very good lectors with few slightly quieter ones.

- Arrangement is very well, thank you. Presentation, if it is possible to sent by e-mail. Discussion, nice place.

- Session I, new ideas, future.

- 1.) Jan Dahl and Jorgen Westergaard. 2.) Discussion on biosecurity.

- Good topics and good discussions with colleagues.

- Networking, discussions.

- Well selected topic and speakers! Nice seminar dinner (tables could have been bigger to allow for more contacts during dinner). 


\section{What could be improved?}

- Speakers from UK must remember that the audience do not have english as 1.st language. Speak more slowly.

- It would have been nice to have more information about the practical things. (Where was lunch on Wednesday confirmation of registration).

- More focus on the future, and not so much about the present situation.

- Gender distribution among speakers. Make sure the achostique is good.

- Better hearing/speaking technic.

- Would have liked to receive presentations in advance so I could have printed since I like to write remarks at the hand outs/powerpoint.

- The seminar "facilities" could be improved, I hope! The sound was very bad in the auditorium. It was difficult (and sometimes impossible) to hear chairmen and participants who asked questions. Even some of the speakers were difficult to hear. When the chairs were pushed on the floor it made the problem worse. Sorry, that I have to focus on this. But it's a pity that a very good programme is spoiled partly by such a simple thing!

- The speakers should be divided 50/50 between male and female speakers.

- The conference had ONE woman as speaker, there must have been possible to invite more female speakers!!! A social activity in the evening to improve networking. The speakers became unavailable for the rest of the group when you placed them at a separate table during dinner!

- Breaks at least every 2 hours! Session III became too long (especially since people became sleepy after lunch).

\section{Suggestions for activities to be dealt with by the Nordic-Baltic} Veterinary Contingency Group in 2013 or 2014

- The different nordic baltic countries give a presentation of the organisation in an emergency situation. The decisions on what level and so on. From start suspicion to lifting the restrictions. And costsharing.

- How could we work even closer to each other (between the Nordic/Baltic countries).

- Involvement of policymakers, farmers (?) or other stakeholders.

- Biosecurity- again. Update on threats to the EU (African Swine Fever, FMD, Rabies etc.)

- Next dinner it should be a mix between organizers, invited speakers and other participants - not an exclusive "organized table" since all 
parties should be able to mix and discuss. Topic - collaboration with the Medical side (and other involved Authorities) during zoonotic outbreaks. It adds a new interesting dimension!

- We talk about one health, but where are they? Suggestion: take a nasty zoonosis, invite the health institutions from all the countries and go through the scenario - who would do what with whom. And/Or a broader theme: cooperation with other authorities and parties to fight an outbreak \& prepare contingency for it. Let the partners present \& explain the pros \& cons of coop. with the vets. The speakers should be from all the participating countries.

- Cooperation between countries on practical level. Next seminar: zoonoses and cooperation with human medicine.

- Glad to hear that biosecurity will be on the agenda!

\subsubsection{Organization chart}

The activities of the Nordic-Baltic Veterinary Contingency Group are carried out within the framework of allocations given to Nordic working group for microbiology and animal health/animal welfare.

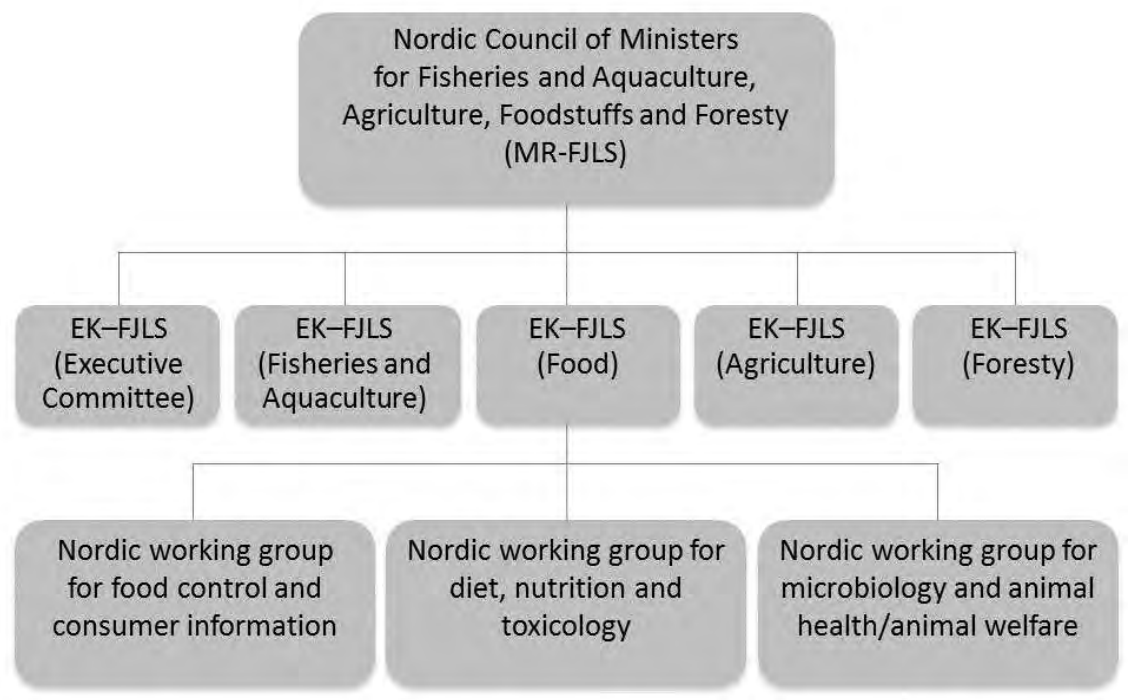


Nordic Council of Ministers

Ved Stranden 18

DK-1061 Copenhagen K

www.norden.org

\section{Contingency Planning for Animal Diseases}

Outbreaks of infectious animal diseases within the last 10-15 years in areas with intensive livestock production have shown how vulnerable the production systems can be when confronted with an outbreak of a highly infectious disease such as avian influenza, foot and mouth disease or classical swine fever. The veterinary administrations of the Nordic and Baltic countries have established contingency plans; the objectives of the plans include:

- to protect animal and human health

- to minimize economic loss for the livestock sector and the society as a whole

- to minimize damage to the environment.

This publication provides information on measures to be considered in contingency planning; the measures take into account:

- the pre-epidemic period; disease prevention

- the epidemic period; disease eradication

- the post-epidemic period; rehabilitation. 